\title{
Ground water quality evaluation near mining area and development of heavy metal pollution index
}

\author{
Bably Prasad · Puja Kumari · Shamima Bano • \\ Shweta Kumari
}

Received: 14 June 2012/ Accepted: 27 August 2013/Published online: 8 September 2013

(C) The Author(s) 2013. This article is published with open access at Springerlink.com

\begin{abstract}
Opencast as well as underground coal mining are likely to disturb the underground water table in terms of quantity as well as quality. Added to this is the problem of leachates from the large number of industrial waste and overburden dumps that are in abundance in mining areas, reaching the ground water and adversely affecting its quality. Enhancement of heavy metals contamination of the ground water is one eventuality. In the present work, concentrations of 7 heavy metals have been evaluated at 20 important ground water sampling stations at Dhanbad township situated very near to Jharia coalfields. The concentration of heavy metals in general was found to be below the permissible levels although concentration of iron and manganese was found above the permissible limits at a few stations. These data have been used for the calculation of heavy metal pollution index (HPI). The HPI of ground water in total was found to be 6.8860 which is far below the critical index limit of 100 pointing to the fact that the ground water is not polluted with respect to heavy metals in spite of the prolific growth of mining and allied industrial activities near the town.
\end{abstract}

Keywords Heavy metal pollution index - Ground water . Coal mining $\cdot$ Heavy metals

B. Prasad $(\square)$

Central Institute of Mining and Fuel Research, Barwa Road, Dhanbad 826015, Jharkhand, India

e-mail: drbablyprasad@yahoo.com

P. Kumari $\cdot$ S. Bano $\cdot$ S. Kumari

Patna A.N. College, Patna, Bihar, India

\section{Introduction}

Opencast as well as underground coal mining disturb the underground water table in terms of its level, quantity as well as quality. Coal mining activity in India started decades back, since then the ground water is getting affected. Along with coal mining, leachates generated from large number of industrial waste and overburden dumps that are in abundance around the mining areas, may reach the ground water and may adversely affect its quality (Khan et al. 2005; Mohammad et al. 2010). Enhancement of heavy metals contamination of the ground water is one of the serious eventualities. Some of the heavy metals considered as micronutrients become detrimental to human health when their concentrations exceed the permissible level of drinking water (Prasanna et al. 2011). Thus, evaluation of heavy metals in ground water that is used for drinking purpose is of great significance from the human health point of view. In the present study, seven important heavy metals such as iron, manganese, lead, copper, cadmium, chromium and zinc have been evaluated in 20 ground water samples, obtained from different places of Dhanbad township which is located very near to Jharia coalfields, for 3 different seasons of the year 2011 and heavy metal pollution index has been evaluated to know the present status of overall pollution level of ground water with respect to heavy metals.

The pollution parameters monitored for the assessment of the quality of any system give an idea of the pollution with reference to that particular parameter only. Quality indices are useful in getting a composite influence of all parameters of overall pollution. Quality indices make use of a series of judgements into a reproducible form and compile all the pollution parameters into some easy approach. Several methods have been proposed to develop 
quality indices for estimation of characteristics of surface water with water quality parameters (Horton 1965; Lohani and Todno 1984; Tiwary and Mishra 1985; Joung et al. 1979; Landwehr 1979; Nishidia et al. 1982). In past years, the authors (Prasad and Jaiprakas 1999; Prasad and Bose 2001; Prasad and Kumari 2008; Prasad and Mondal 2008) have evaluated the heavy metals pollution in ground water and evaluated heavy metal pollution index (HPI).

\section{Indexing approach}

The HPI represents the total quality of water with respect to heavy metals. The proposed HPI is based on weighted arithmetic quality mean method and is developed on two basic steps: firstly, by establishing a rating scale for each selected parameter giving weightage to selected parameter (heavy metal) and, secondly, by selecting the pollution parameter on which the index is to be based. Rating system is an arbitrary value between 0 and 1 , and its selection depends upon the importance of individual quality considerations in a comparative way, or it can be assessed by making values inversely proportional to the recommended standard for the corresponding parameter (Horton 1965; Mohan et al. 1996). In the present formula, unit weightage $\left(W_{i}\right)$ is taken as value inversely proportional to the recommended standard $\left(S_{i}\right)$ of the corresponding parameter. Iron, manganese, lead, copper, cadmium, chromium and zinc have been monitored for the model index application. The HPI model proposed is given by Mohan et al. (1996)

$\mathrm{HPI}=\frac{\sum_{i=1}^{n} W_{i} Q_{i}}{\sum_{i=1}^{n} W_{i}}$

where $Q_{i}$ is the sub index of the $i$ th parameter. $W_{i}$ is the unit weightage of $i$ th parameter and $n$ is the number of parameters considered.

The sub index $\left(Q_{i}\right)$ of the parameter is calculated by

$Q_{i}=\sum_{i=1}^{n} \frac{\left\{M_{i}(-) I_{i}\right\}}{\left(S_{i}-I_{i}\right)} \times 100$

where, $M_{i}$ is the monitored value of heavy metal of $i$ th parameter, $I_{i}$ is the ideal value of $i$ th parameter, $S_{i}$ is the standard value of $i$ th parameter. The sign (-) indicates the numerical difference of the two values, ignoring the algebraic sign.

Generally, pollution indices are estimated for any specific use of the water. The proposed index is intended for the purpose of drinking water. The critical pollution index value for drinking water is 100 .
Fig. 1 Map showing water sampling points in Dhanbad township area

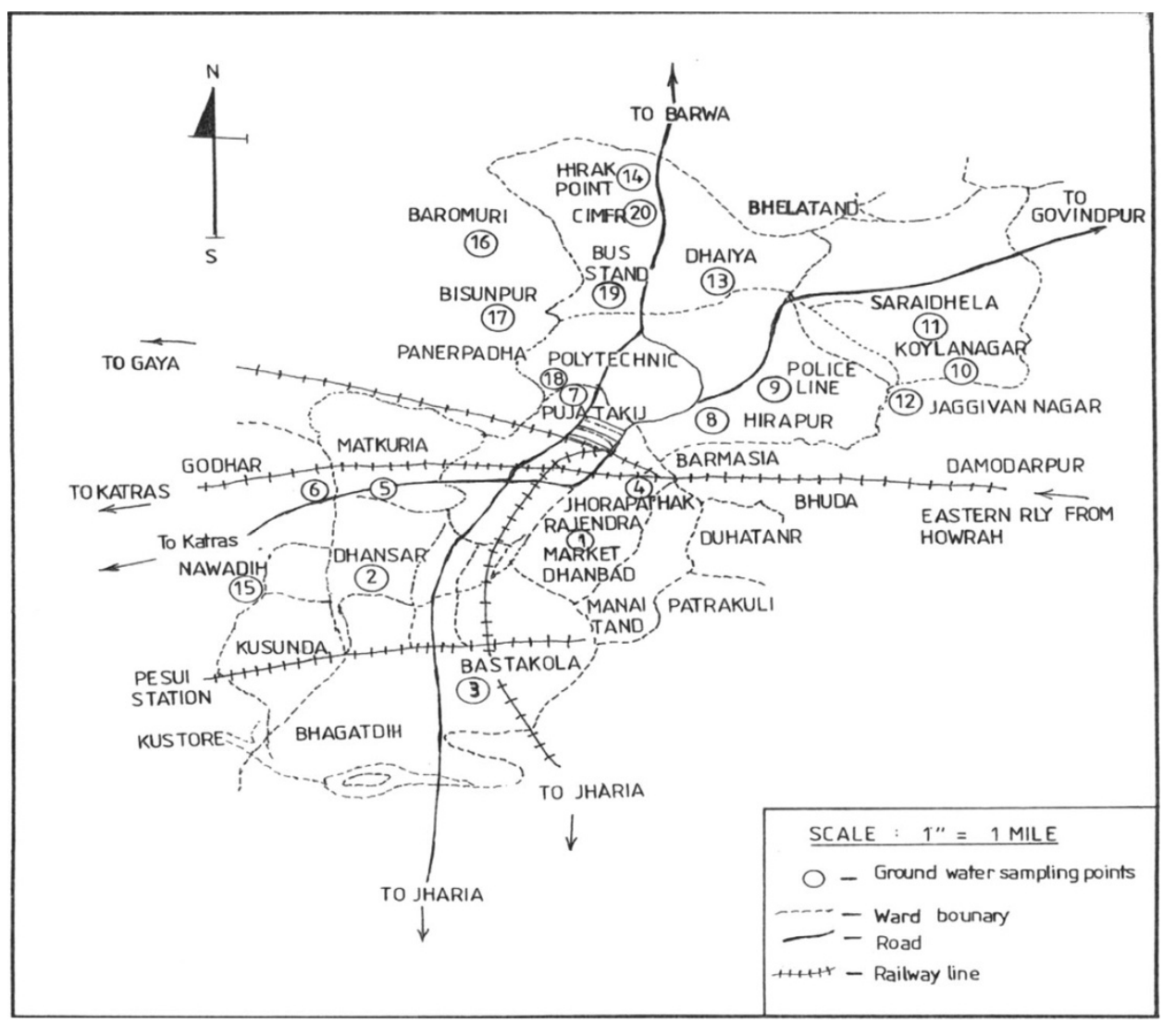


Table 1 Total heavy metals concentration (ppm) in ground water of Dhanbad town

\begin{tabular}{|c|c|c|c|c|c|c|c|c|c|c|c|c|}
\hline \multirow[t]{2}{*}{ S1 no. } & \multicolumn{3}{|c|}{$\begin{array}{l}\text { Analysis of copper mean } \\
\text { concentration } 0.0084\end{array}$} & \multicolumn{3}{|c|}{$\begin{array}{l}\text { Analysis of manganese mean } \\
\text { concentration } 0.1662\end{array}$} & \multicolumn{3}{|c|}{$\begin{array}{l}\text { Analysis of lead mean } \\
\text { concentration } 0.0038\end{array}$} & \multicolumn{3}{|c|}{$\begin{array}{l}\text { Analysis of iron mean } \\
\text { concentration } 0.5416\end{array}$} \\
\hline & $\begin{array}{l}\text { Summer } \\
\text { season }\end{array}$ & $\begin{array}{l}\text { Rainy } \\
\text { season }\end{array}$ & $\begin{array}{l}\text { Winter } \\
\text { season }\end{array}$ & $\begin{array}{l}\text { Summer } \\
\text { season }\end{array}$ & $\begin{array}{l}\text { Rainy } \\
\text { season }\end{array}$ & $\begin{array}{l}\text { Winter } \\
\text { season }\end{array}$ & $\begin{array}{l}\text { Summer } \\
\text { season }\end{array}$ & $\begin{array}{l}\text { Rainy } \\
\text { season }\end{array}$ & $\begin{array}{l}\text { Winter } \\
\text { season }\end{array}$ & $\begin{array}{l}\text { Summer } \\
\text { season }\end{array}$ & $\begin{array}{l}\text { Rainy } \\
\text { season }\end{array}$ & $\begin{array}{l}\text { Winter } \\
\text { season }\end{array}$ \\
\hline $\begin{array}{l}\text { 1. Open } \\
\text { well }\end{array}$ & 0.00288 & 0.00128 & 0.0020 & 0.00426 & 0.00334 & 0.0023 & 0.00546 & BDL & 0.0041 & 0.06662 & 0.06868 & 0.0269 \\
\hline $\begin{array}{l}\text { 2. Open } \\
\text { well }\end{array}$ & 0.00376 & 0.01016 & 0.0035 & 0.24986 & 0.07062 & 0.0833 & 0.00276 & BDL & 0.0002 & 0.02406 & 0.07568 & 0.0258 \\
\hline $\begin{array}{l}\text { 3. Open } \\
\text { well }\end{array}$ & 0.00386 & 0.00292 & 0.0032 & 0.03598 & 0.0943 & 0.0825 & 0.04874 & 0.00866 & BDL & 0.09322 & 0.04428 & 0.0211 \\
\hline $\begin{array}{l}\text { 4. Hand } \\
\text { pump }\end{array}$ & 0.03268 & 0.00854 & 0.0069 & 0.01146 & 0.03292 & 0.0475 & BDL & 0.02612 & BDL & 0.4181 & 0.1193 & 1.2607 \\
\hline $\begin{array}{l}\text { 5. Hand } \\
\text { pump }\end{array}$ & 0.00532 & 0.00706 & 0.0052 & 0.03468 & 0.10076 & 0.0515 & 0.00258 & 0.00194 & 0.0002 & 1.39866 & 0.11532 & 0.1219 \\
\hline $\begin{array}{l}\text { 6. Hand } \\
\text { pump }\end{array}$ & 0.00236 & 0.00256 & 0.0035 & 0.37404 & 0.28494 & 0.3351 & BDL & 0.00164 & 0.0005 & 0.43802 & 0.18056 & 0.0928 \\
\hline $\begin{array}{l}\text { 7. Hand } \\
\text { pump }\end{array}$ & 0.01072 & 0.00728 & 0.0060 & 0.1107 & 0.12938 & 0.1079 & 0.0009 & 0.011 & 0.0008 & 0.38542 & 0.342 & 0.1148 \\
\hline $\begin{array}{l}\text { 8. Hand } \\
\text { pump }\end{array}$ & 0.00904 & 0.00744 & 0.0048 & 0.0077 & 0.00844 & 0.0315 & BDL & 0.002 & 0.0005 & 1.667 & 0.80368 & 0.4548 \\
\hline $\begin{array}{l}\text { 9. Hand } \\
\text { pump }\end{array}$ & 0.01428 & 0.00642 & 0.0341 & 0.19608 & 0.20364 & 0.1758 & BDL & 0.00108 & 0.0130 & 1.98606 & 0.86664 & 5.5744 \\
\hline $\begin{array}{l}\text { 10. Hand } \\
\text { pump }\end{array}$ & 0.00128 & 0.0082 & 0.0052 & 0.00616 & 0.8954 & 0.0067 & BDL & 0.00404 & 0.0023 & BDL & 0.11726 & 0.0011 \\
\hline $\begin{array}{l}\text { 11. Hand } \\
\text { pump }\end{array}$ & 0.03148 & 0.00874 & 0.0258 & 1.24586 & 1.6652 & 1.6060 & 0.00154 & 0.0097 & 0.0002 & 0.0793 & 0.7385 & 0.3856 \\
\hline $\begin{array}{l}\text { 12. Hand } \\
\text { pump }\end{array}$ & 0.00164 & 0.00458 & 0.0123 & 0.00024 & 0.05184 & 0.0903 & BDL & 0.01198 & 0.0023 & BDL & 0.25904 & 0.4075 \\
\hline $\begin{array}{l}\text { 13. Hand } \\
\text { pump }\end{array}$ & 0.00594 & 0.0064 & 0.0068 & 0.02932 & 0.05458 & 0.0444 & BDL & 0.00194 & BDL & 0.164898 & 0.4932 & 0.1826 \\
\hline $\begin{array}{l}\text { 14. Hand } \\
\text { pump }\end{array}$ & 0.00292 & 0.00488 & 0.0047 & 0.09238 & 0.13662 & 0.0468 & 0.00038 & 0.01482 & 0.0050 & 0.0011 & 0.16778 & 0.2142 \\
\hline $\begin{array}{l}\text { 15. Hand } \\
\text { pump }\end{array}$ & 0.00818 & 0.0354 & 0.0043 & 0.00426 & 0.16624 & 0.1410 & 0.00142 & 0.00766 & 0.0015 & 0.55062 & 0.22474 & 0.1436 \\
\hline $\begin{array}{l}\text { 16. Hand } \\
\text { pump }\end{array}$ & 0.00582 & 0.0122 & 0.0153 & 0.00928 & 0.00934 & 0.0139 & 0.00044 & 0.0055 & 0.0046 & 0.68896 & 0.32732 & 2.6000 \\
\hline $\begin{array}{l}\text { 17. Hand } \\
\text { pump }\end{array}$ & 0.01396 & 0.00546 & 0.0087 & 0.01524 & 0.024 & 0.0216 & 0.00212 & 0.00048 & 0.0016 & 2.45064 & 0.4402 & 1.5932 \\
\hline $\begin{array}{l}\text { 18. Hand } \\
\text { pump }\end{array}$ & 0.0023 & 0.00232 & 0.0030 & 0.16788 & 0.18452 & 0.0421 & BDL & 0.00128 & 0.0017 & 0.37826 & 0.25584 & 0.3166 \\
\hline $\begin{array}{l}\text { 19. Hand } \\
\text { pump }\end{array}$ & 0.00782 & 0.00326 & 0.0067 & 0.1011 & 0.07128 & 0.0242 & BDL & 0.01136 & 0.0011 & 0.81092 & 0.66894 & 0.4460 \\
\hline $\begin{array}{l}\text { 20.Open } \\
\text { well }\end{array}$ & 0.00354 & 0.00622 & 0.0255 & 0.00848 & 0.06432 & 0.0637 & 0.00044 & 0.00084 & 0.0036 & 0.12258 & 0.35644 & 0.1258 \\
\hline
\end{tabular}

\section{Materials and methods}

Study area

Dhanbad, one of the biggest coal belts of India, is actively associated in mining activities for more than a century. The oldest geological formations of the Dhanbad district are composed of crystalline metamorphic rocks which belong to Dharwar system in Indian stratigraphy. In these formations are found rock types of both sedimentary and igneous origin. Course gritty soil is predominant in Dhanbad coal basin. This type of soil mixed with big fragment of rocks is formed from the weathering of pegmatites, quartz and conglomeratic sandstones. About 200 coal mines of Jharia coal fields, which produce prime coking coal, are located around Dhanbad township. The large scale industries like coal washing and coke making are located nearby. There is drinking water shortage in the 
township, especially in summer season. Population here is mainly depended on ground water sources. Taking all these into consideration, twenty ground water sampling points have been selected, which covered almost entire township of Dhanbad (Fig. 1).

Sampling and analysis

Out of 20, 4 samples have been taken from open well and 16 from hand pumps. The depth of open wells was $25-30 \mathrm{~m}$ and that of hand pumps $100-120 \mathrm{~m}$. Sampling has been done for the month of May (summer) 2011, August (rainy) 2011 and December (winter) 2011 to get an idea of the seasonal variation of the heavy metal concentrations. All samples have been digested, concentrated and prepared for analysis by atomic absorption spectrophotometer (AAS) methods using model: M Series Thermo Fisher (Arnold et al. 1992). The digestion and concentration of water sample was carried out by reducing the volume of 1,000-50 ml by slow heating on a hot plate with addition of few millilitres of concentrated nitric acid. Slow heating was done to avoid metal loss due to evaporation. Analysis of these metals were performed by calibrating the instrument with different dilutions of standard solutions and analysis of $\mathrm{Cu}, \mathrm{Mn}, \mathrm{Pb}, \mathrm{Fe}, \mathrm{Cd}, \mathrm{Zn}$ and $\mathrm{Cr}$ was performed at 324.7, 279.5, 217.0, 248.3, 228.8, 213.9 and $357.9 \mathrm{~nm}$, respectively. Three replicates were run for each sample and the instrument was recalibrated after analysis of ten samples. The detection limit of AAS was well within the range for all elements analysed. Over all precision expressed as percent relative standard deviation was obtained for all the samples. Because the samples were concentrated during digestion, the result obtained was calculated to get the actual concentration.

\section{Result and discussion}

The evaluation of concentration of seven heavy metals such as $\mathrm{Fe}, \mathrm{Mn}, \mathrm{Pb}, \mathrm{Cu}, \mathrm{Cd}, \mathrm{Cr}$, and $\mathrm{Zn}$ in three seasons in ground water of Dhanbad town is listed in Tables 1 and 2 . The mean concentrations of $\mathrm{Fe}, \mathrm{Mn}, \mathrm{Pb}, \mathrm{Cu}, \mathrm{Cd}, \mathrm{Cr}$, and $\mathrm{Zn}$ were $0.5416,0.1662,0.0038,0.0084,0.00041,0.0072$ and $0.2116 \mathrm{mg} / \mathrm{l}$, respectively, which include total twenty ground water sampling points for three seasons of the year. From the results, it has been observed that concentrations of heavy metals such as $\mathrm{Cu}, \mathrm{Pb}$, and $\mathrm{Zn}$ were well below the permissible limits of Indian drinking water standard (IS: 10500). The concentration of $\mathrm{Mn}$ and $\mathrm{Fe}$ has been found more than the highest desirable limit of drinking

Table 2 Total heavy metal concentration (ppm) in ground water of Dhanbad town

\begin{tabular}{|c|c|c|c|c|c|c|c|c|c|}
\hline \multirow[t]{2}{*}{ S1 no. } & \multicolumn{3}{|c|}{$\begin{array}{l}\text { Analysis of cadmium mean concentration } \\
0.00041\end{array}$} & \multicolumn{3}{|c|}{$\begin{array}{l}\text { Analysis of zinc mean concentration } \\
0.2116\end{array}$} & \multicolumn{3}{|c|}{$\begin{array}{l}\text { Analysis of chromium mean concentration } \\
0.0072\end{array}$} \\
\hline & $\begin{array}{l}\text { Summer } \\
\text { season }\end{array}$ & $\begin{array}{l}\text { Rainy } \\
\text { season }\end{array}$ & $\begin{array}{l}\text { Winter } \\
\text { season }\end{array}$ & $\begin{array}{l}\text { Summer } \\
\text { season }\end{array}$ & $\begin{array}{l}\text { Rainy } \\
\text { season }\end{array}$ & $\begin{array}{l}\text { Winter } \\
\text { season }\end{array}$ & $\begin{array}{l}\text { Summer } \\
\text { season }\end{array}$ & $\begin{array}{l}\text { Rainy } \\
\text { season }\end{array}$ & $\begin{array}{l}\text { Winter } \\
\text { season }\end{array}$ \\
\hline 1. Open well & BDL & BDL & BDL & 0.01518 & 0.02224 & 0.0152 & BDL & BDL & BDL \\
\hline 2. Open well & 0.0001 & 0.002 & 0.0004 & 0.09618 & 0.07168 & 0.1080 & BDL & $\mathrm{BDL}$ & 0.0006 \\
\hline 3. Open well & BDL & $\mathrm{BDL}$ & 0.0002 & BDL & 0.14132 & 0.1085 & BDL & BDL & 0.0023 \\
\hline 4. Hand pump & $\mathrm{BDL}$ & 0.00024 & BDL & 0.22426 & 0.14774 & 0.0988 & 0.0041 & 0.00708 & 0.0054 \\
\hline 5. Hand pump & 0.00084 & BDL & BDL & 0.17224 & 0.19492 & 0.0091 & BDL & 0.02488 & 0.0062 \\
\hline 6. Hand pump & BDL & 0.00562 & BDL & 0.01044 & 0.02196 & 0.0377 & BDL & 0.06444 & 0.0022 \\
\hline 7. Hand pump & 0.00194 & BDL & BDL & 0.02616 & 0.03656 & 0.0198 & BDL & 0.0198 & 0.0037 \\
\hline 8. Hand pump & BDL & 0.00066 & BDL & 0.28182 & 0.05214 & 0.0322 & 0.00154 & 0.01022 & 0.0044 \\
\hline 9. Hand pump & BDL & 0.00238 & 0.0003 & 0.01904 & 0.02052 & 1.5246 & 0.00028 & 0.01888 & 0.0094 \\
\hline 10. Hand pump & 0.00156 & BDL & BDL & 0.0376 & 2.7842 & 0.0545 & BDL & 0.01568 & 0.0021 \\
\hline 11. Hand pump & BDL & 0.00078 & 0.0002 & 0.0972 & 0.0386 & 0.0746 & 0.0066 & 0.04586 & 0.0131 \\
\hline 12. Hand pump & BDL & 0.00022 & BDL & BDL & 0.9836 & 0.4922 & 0.0012 & 0.04424 & 0.0057 \\
\hline 13. Hand pump & 0.00484 & BDL & BDL & 0.03118 & 0.03474 & 0.0207 & 0.00264 & 0.02152 & 0.0046 \\
\hline 14. Hand pump & $\mathrm{BDL}$ & 0.00004 & BDL & 0.03238 & 0.0362 & 0.0241 & 0.00362 & 0.01262 & 0.0029 \\
\hline 15. Hand pump & 0.0043 & 0.00068 & BDL & 0.07752 & 1.9594 & 0.1496 & 0.00158 & BDL & 0.0056 \\
\hline 16. Hand pump & BDL & 0.0004 & BDL & 0.17704 & 0.14574 & 0.4326 & 0.00118 & 0.00282 & 0.0057 \\
\hline 17. Hand pump & BDL & 0.00004 & BDL & 0.0227 & 0.02808 & 0.1496 & 0.00244 & 0.00992 & 0.0052 \\
\hline 18. Hand pump & BDL & BDL & BDL & 0.0687 & 0.02 & 0.0152 & 0.00118 & 0.00904 & 0.0032 \\
\hline 19. Hand pump & BDL & BDL & BDL & 0.46866 & 0.09144 & 0.1377 & 0.00228 & 0.0047 & 0.0062 \\
\hline 20.Open well & BDL & BDL & BDL & 0.07846 & 0.04796 & 0.3769 & 0.00286 & 0.00034 & 0.0024 \\
\hline
\end{tabular}


Table 3 HPI calculation for ground water of Dhanbad town

\begin{tabular}{lcrclcl}
\hline $\begin{array}{l}\text { Heavy } \\
\text { metals }\end{array}$ & $\begin{array}{l}\text { Mean value } \\
(\mathrm{ppb}) M_{i}\end{array}$ & $\begin{array}{l}\text { Standard permissible } \\
\text { value.(ppb) } S_{i}\end{array}$ & $\begin{array}{l}\text { Highest desirable } \\
\text { value }(\mathrm{ppb}) I_{i}\end{array}$ & $\begin{array}{l}\text { Unit } \\
\text { weightage } \\
\left(W_{i}\right)\end{array}$ & $\begin{array}{l}\text { Sub } \\
\text { index } \\
\left(Q_{i}\right)\end{array}$ & $W_{i} \times \mathrm{Q}_{i}$ \\
\hline $\mathrm{Cu}$ & 8.4 & 1,500 & 50 & 0.0006 & 2.86 & 0.0017 \\
$\mathrm{Mn}$ & 166.2 & 300 & 100 & 0.0033 & 33.1 & 0.1092 \\
$\mathrm{Zn}$ & 211.6 & 15,000 & 5,000 & 0.00006 & 47.88 & 0.0028 \\
$\mathrm{~Pb}$ & 3.8 & 50 & - & 0.02 & 7.6 & 0.152 \\
$\mathrm{Fe}$ & 541.6 & 1,000 & 300 & 0.001 & 34.51 & 0.0345 \\
$\mathrm{Cd}$ & 0.41 & 10 & - & 0.1 & 4.1 & 0.410 \\
$\mathrm{Cr}$ & 7.2 & 50 & - & 0.02 & 14.4 & 0.288 \\
\hline
\end{tabular}

Table 4 Heavy metal pollution index of various sampling stations

Mean HPI $=8.2091$

\begin{tabular}{lllrr}
\hline S1 no. & Sampling point & Ground water source & HPI & \% Deviation \\
\hline 1 & Rajendra market & Open well & 2.2544 & -72.5377 \\
2 & Dhansar & Open well & 6.7549 & -17.7144 \\
3 & Bastakola & Open well & 6.5569 & -20.1264 \\
4 & Joraphatak & Hand pump & 5.5905 & -31.8987 \\
5 & Matkuria 1 & Hand pump & 5.9271 & -27.7984 \\
6 & Matkuria 2 & Hand pump & 22.2770 & +171.3690 \\
7 & Puja talkies & Hand pump & 7.9932 & -2.6300 \\
8 & Court more & Hand pump & 4.8868 & -40.4709 \\
9 & Police line & Hand pump & 13.6258 & +65.9840 \\
10 & Koyla nagar & Hand pump & 8.4326 & +2.7225 \\
11 & Steel gate & Hand pump & 25.4608 & +210.1533 \\
12 & Jagjivan nagar & Hand pump & 7.0798 & -13.7566 \\
13 & Dhaiya & Hand pump & 14.5198 & +76.8744 \\
14 & Hirak point & Hand pump & 4.0044 & -51.2199 \\
15 & Nawadih & Hand pump & 13.1552 & +60.2514 \\
16 & Baromuri & Hand pump & 4.7178 & -42.5296 \\
17 & Bisanpur & Hand pump & 4.2025 & -48.8068 \\
18 & Polytechnique & Hand pump & 1.9161 & -76.6588 \\
19 & Bus stand & Hand pump & 3.1181 & -62.0165 \\
20 & CIMFR & Open well & 1.7094 & -79.1767 \\
\hline
\end{tabular}

water standard at many places, in all seasons, especially in hand pumps water samples. The concentration of $\mathrm{Fe}$ in summer has exceeded the highest permissible value of $1.5 \mathrm{mg} / \mathrm{l}$ at sampling points 8,9 , and 17 and in winters at sampling points 8,16 and 17 . This phenomenon may be due to corroded nature of iron pipes of hand pumps or due to presence of more iron in ground strata bearing the ground water. In general, highest concentration of $\mathrm{Mn}$ and $\mathrm{Fe}$ in hand pump water samples indicates the poor quality and maintenance of hand pumps. The open well water samples collected at sampling point $1,2,3$, and 20 show that none of the water samples are having higher concentration of any heavy metals under study except $\mathrm{Mn}$ at sampling point 2 in summer season and $\mathrm{Fe}$ at sampling point 20 in rainy season. Since the weightage $\left(W_{i}\right)$ given to $\mathrm{Fe}$ and $\mathrm{Mn}$ is very less, so in evaluation of HPI of ground water in total, these parameters do not contribute much on HPI value.
Heavy metals like $\mathrm{Pb}, \mathrm{Cd}$, and $\mathrm{Cr}$ have been given no relaxation in drinking water standard and they have been given high weightage $\left(W_{i}\right)$ value in HPI calculation. Hence even their smaller concentration present in water samples makes the water of poor quality and gives high values in HPI calculations. Concentration of $\mathrm{Cu}$ and $\mathrm{Zn}$ has not been found at any sampling point and at any season higher than the highest desirable limit of drinking water standard. Overall, the ground water of Dhanbad town with respect to heavy metals contamination is not a serious issue and ground water contamination of the township is not taking place due to severe coal mining activity near the township. The monitored data of ground water samples have been used to evaluate the HPI and assess the validity of the index model. The HPI has been determined by taking the mean concentration of heavy metals of all the three seasons using Eqs. 1 and 2. In Table 3 detailed calculation of pollution 
Table 5 HPI values at different seasons

\begin{tabular}{lll}
\hline $\begin{array}{l}\text { Sampling } \\
\text { month }\end{array}$ & $\begin{array}{l}\text { Heavy metal pollution } \\
\text { index }\end{array}$ & $\begin{array}{l}\text { \% Deviation with mean } \\
\text { HPI value }\end{array}$ \\
\hline Summer & 6.2044 & -10.8511 \\
Rainy & 11.4717 & +64.8327 \\
Winter & 3.2028 & -53.9801 \\
\hline
\end{tabular}

Mean HPI $=6.9596$

index with unit weightage $\left(W_{i}\right)$, standard permissible value $\left(S_{i}\right)$, monitored concentration value $\left(M_{i}\right)$ and highest desirable value $\left(I_{i}\right)$ has been done. The HPI calculated with mean concentration values of all metals including all sampling points of ground water for three seasons of the year 2011 comes out to be 6.8860 which is far below the critical index value of 100 . The same study carried out earlier and HPI calculated for Dhanbad township ground water was 11.2531 (Prasad and Jaiprakas 1999). This indicated that even after continuous mining activity near the township for years, the ground water has not been contaminated by higher concentrations of heavy metals. The calculated HPI value indicates that, in general, the ground water is not contaminated with respect to heavy metals pollution. The heavy metal pollution index calculated for all 20 sampling locations and all seasons is given in Tables 4 and 5, respectively. This enables us to assess the quality of ground water at each sampling station which can be used to compare the quality with each other. Percentage deviation and mean deviation with mean HPI value are also calculated for each sampling location. At all sampling points, HPI calculated is below the critical index limit of 100 but at sampling point 6, 9,11,13 and 15 which are shallow hand pumps, the index value is high as compared to other sampling station. All other sampling locations indicate lower value of HPI as compared to mean HPI of 8.2091 (Table 4) and the percentage deviation is negative side. More negative deviation shows better quality of ground water and more positive deviation shows deteriorated quality of ground water. The lowest HPI value of 1.7094 has been obtained at sampling point 20 which is an open well and highest HPI value of 25.4608 at sampling point 11 which is a hand pump.

In Table 5, calculation of HPI has been done separately for three seasons May (summer), August (rainy) and December (winter) months. Rainy season HPI shows highest value of 11.4717 and percentage deviation is positive +64.8327 with mean HPI of 6.9596 . Highest HPI in rainy season indicates that due to rain, many heavy metals from the surface of the ground may leach out to ground water. The HPI of summer and winter season is 6.2044 and 3.2028 which is lesser than the mean HPI and percentage deviation is -10.8511 and -53.9801 , respectively. Lowest HPI in winter season with maximum negative percentage deviation indicates the best quality of ground water in winter season. This method has been found very useful to calculate the overall pollution level of ground water with respect to heavy metals.

\section{Conclusion}

The present mean HPI calculated for ground water of Dhanbad town has been found to be 6.8860 which is far below the critical index limit of 100. In our earlier study, which was carried out in 1997 for the same work, it was found that the mean HPI of Dhanbad township was 11.2531 (Prasad and Jaiprakas 1999). This indicates that after passing of several years still the ground water of the mining town is not polluted with respect to heavy metals. In addition, the several years of coal mining activity taking place near the township has not affected the ground water quality with respect to heavy metals. This method of evaluating the overall pollution level of ground water with respect to heavy metals is a very useful.

Acknowledgments Authors are grateful to Dr. Amalendu Sinha, Director of Central Institute of Mining and Fuel Research, Dhanbad, India for the support during the investigation period.

Open Access This article is distributed under the terms of the Creative Commons Attribution License which permits any use, distribution, and reproduction in any medium, provided the original author(s) and the source are credited.

\section{References}

Arnold EG, Lemore SC, Andrew DE, American Public Health Association (1992) Standard methods for the examination of water and wastewater APHA, 18th edn

Bhuiyan MAH, Islam MA, Dampare SB, Parvez L, Shigeyuki S (2010) Evaluation of hazardous metal pollution in irrigation and drinking water systems in the vicinity of a coal mine area of Northwest Bangladesh. J Hazard Mater 179:1065-1077

Horton RK (1965) An index number systems for rating water quality. J Water Pollut Control Fed 3:300

Joung HM, Miller WW, Mahammah CN, Gultjens JCA (1979) A generalised water quality index based on multivariate factor analysis. J Environ Qual 8:95

Khan R, Israili SH, Ahmad H, Mohan A (2005) Heavy metal pollution assessment in surface water bodies and its suitability for irrigation around the Neyveli lignite mines and associated industrial complex, Tamil Nadu, India. Mine Water Environ 24:155-161

Landwehr TM (1979) A statistical view of a class of water quality indices. Water Resour Res 15:460

Lohani BN, Todno M (1984) Water quality index for chao phraya river. J Environ Eng Div (ASCE) 110:1163-1176

Mohan SV, Nithila P, Reddy SJ (1996) Estimation of heavy metal in drinking water and development of heavy metal pollution index. J Environ Sci Health A31(2):283 
Nishidia N, Miyai M, Tada F, Suzuki S (1982) Computation of index of pollution by heavy metals in river water. Environ Pollut 4:241

Prasad B, Bose JM (2001) Evaluation of heavy metal pollution index for surface and spring water near lime stone mining area of lower Himalayas. Environ Geol 41(1/2):183-188

Prasad B, Jaiprakas KC (1999) Evaluation of heavy metals in ground water near mining area and development of heavy metal pollution index. J Environ Sci Health (USA) A 34(1):91-102

Prasad B, Kumari S (2008) Heavy metal pollution index of ground water of an abandoned opencast mine filled with fly ash. Mine Water Environ 27(4):265-267
Prasad B, Mondal KK (2008) The impact of filling an abandoned open cast mine with fly ash on groundwater quality: a case study. Mine Water Environ 27:40-45

Prasanna MV, Chitambaram S, Hameed AS, Srinivasamoorthy K (2011) Hydrogeochemical analysis and evaluation of groundwater quality in the Gadilam river basin, Tamil Nadu, India. J Earth Syst Sci 120(1):85-98

Tiwary TN, Mishra M (1985) A preliminary assignment of water quality index to major Indian rivers. J Environ Prot 5:276 